\title{
Survey of Powdery Mildew in Major Cucumber Growing Areas of Northern Karnataka, India
}

\author{
H. Parameshwar Naik* and Shripad Kulkarni \\ Department of Plant Pathology, College of Agriculture, UAS, Dharwad-580005, \\ Karnataka, India \\ *Corresponding author
}

\section{A B S T R A C T}

\section{Keywords \\ Cucumber, Survey, Powdery mildew, Karnataka \\ Article Info \\ Accepted: \\ 23 March 2018 \\ Available Online: \\ 10 April 2018}

\begin{abstract}
Powdery mildew is very important foliar disease of cucumber among major cucurbits growing areas of Karnataka which results in huge economic loss. Disease first appear on the leaves thirty days after sowing and continue to produce white mycelial growth on various aerial plant parts up to the harvest. Survey results revealed that the disease severity of powdery mildew in all the cucumber growing areas of northern Karnataka is low to severe $(10.25$ to $63.08 \%)$. The disease severity was varied among different stage of the crop and varieties grown but there was no significant difference among the cultivation practices. Maximum mean disease severity was recorded in Dharwad district 33.06 per cent, whereas minimum disease severity was recorded in Belagavi with 27.21 per cent.
\end{abstract}

\section{Introduction}

Cucumber (Cucumis sativa L.) is a popular fresh market vegetable preferred for several food stuffs and is cultivated throughout India. The total area under cucumber cultivation in India is 71000 hectare with a production of 1202000 tonnes with an average productivity of 16.92 tonnes (Anon, 2015-16). Powdery mildew is a serious disease and causes considerable yield loss to the number of cucurbitaceous crops grown in India. Its distribution and relative occurrence varies throughout the world. Most of the cucurbits are found susceptible to powdery mildew disease but few cucurbits are not much infected due to resistant cultivars. This disease reduces the yield by interfering with photosynthetic activity and biochemical imbalance. Till date across the world more than eight genera have been reported from order Erysiphales. Among them Erysiphe cichoracearum, Sphaerotheca fuliginea and Levilulla taurica are the major pathogens.

Cucumber powdery mildew caused by Erysiphe cichoracearum and Sphaerotheca fuliginea has worldwide importance and it is considered to be one of the most devastating diseases as its occurrence and incidence assumes greater significance resulting in reduction of fruit yield. Powdery mildew and downy mildew together causes up to 50-70 per cent a loss (Sitterly, 1972 and Awad, 2000). In 
the present study survey was conducted to know the disease severity of powdery mildew of cucumber in major cucumber growing areas of northern Karnataka in open field as well as protected structures. Among the cucurbits, Lagenaria siceraria and Cucurbita moschata have recorded highest disease and also the wild cucurbit Coccinia cardifolia (Gangwar and Mishra, 2014).

\section{Materials and Methods}

A roving survey for severity of powdery mildew of cucumber was conducted in Belagavi, Haveri, Dharwad and Vijaypuraa districts of northern Karnataka during late kharif 2016-17. The information on cucumber growing areas was collected from respective districts of horticulture department. Details of individual fields visited and necessary information on disease severity was recorded. During the survey cucumber fields were observed for powdery mildew severity, stage of crop and other details were recorded. In open field conditions five plants were randomly selected and severity was recorded by following 0-9 scale through visual observation (Mayee and Datar, 1986) as given below.

Per cent disease index (PDI) was calculated by using formula given by Wheeler (1969).

Sum of the all individual disease ratings PDI =

Total number of plants observed $\mathrm{x}$ Maximum grade

\section{Results and Discussion}

A roving survey was carried out in Dharwad, Haveri, Belagavi and Vijaypura districts of northern Karnataka during late kharif 2016 to find out the severity of powdery mildew of cucumber. Twenty seven locations in Belagavi, sixteen locations in Dharwad, thirty places in Haveri and eleven locations in Vijaypura (total eighty four cucumber fields) were surveyed as explained in Material and Methods. The results are presented in Table $1 \mathrm{a}, 1 \mathrm{~b}, 1 \mathrm{c}, 1 \mathrm{~d}, 1 \mathrm{e}$, figure $1,2,3,4$, and plate 1 .

Maximum mean percent disease severity (PDI) was observed in Dharwad district (33.06 PDI) followed by Haveri district (29.87 PDI) and minimum mean percent disease severity (PDI) was observed in Belagavi (27.21 PDI) district and it is on par with Vijaypuraa district (27.60 PDI).

In Dharwad district, two taluka's were surveyed, Viz., Dharwad and Hubli. In Dharwad taluka the survey was conducted in sixteen villages. Among them, the maximum severity (59.66 \%) was recorded at MARS, Dharwad followed by Tadakoda village with a severity of (40.86\%) whereas, least severity (12.25\%) was recorded in Mrutyunjay nagar. Similarly in Hubli taluka the maximum severity (43.29 \%) was recorded in Saunshi followed by Adaragunchi with the severity of 42.78 per cent. The least severity $(13.53 \%)$ of powdery mildew was recorded in Ramanakoppa village.

In Haveri district, five taluka's were surveyed, viz., Haveri, Ranebennur, Hirekerur, Shiggaon and Byadgi. In Haveri taluka the survey was conducted in five villages. Among them the maximum severity $(29.66 \%)$ was recorded in Vardi cross followed by Motebennur village with a severity of 26.36 per cent. Whereas least severity $(20.15 \%)$ was recorded in Kerimathihalli village. Similarly in Ranebennur taluka the maximum severity $(58.15 \%)$ was recorded in Basirikatti village followed by Medleri with the severity of 40.19 per cent whereas, the least severity of 18.66 per cent was recorded in Chalageri.

Similarly in Shiggaon taluka the maximum severity $(36.25 \%)$ was recorded in Gotagodi 
followed by Shiggaon with the severity of $30.78 \%$ per cent, the least incidence $(22.18$ $\%)$ was recorded in Niralgi. In Byadgi taluka maximum severity $(40.18 \%)$ was recorded in Angargatti whereas the least severity (21.12 $\%$ ) was recorded in Mallur. Similarly in Hirekurur taluka maximum severity $(39.55 \%)$ was recorded in Masur, least severity (20.48 $\%)$ was recorded in Bannihatti. Among the talukas surveyed in Haveri district the maximum severity (32.84 \%) was recorded in Byadgi and least severity was recorded in Haveri taluka (24.49\%).

In Belagavi district, four taluka's were surveyed, Viz., Belagavi, Bailhongal, Savadatti and Gokak. In Belagavi taluka the survey was conducted in five villages. Among them the maximum severity $(29.18 \%)$ was recorded in Sutagatti village followed by Hulikatti village with severity of $24.15 \%$ per cent recorded, whereas least severity (10.25 $\%$ ) was recorded in K. K Koppa village. Similarly in Bailhongal the survey was conducted in nine villages, among them maximum severity (63.08 \%) was recorded in Bailwad cross followed by Kadrohalli village with the severity $(36.17 \%)$ whereas the least severity (20.79 \%) was recorded in Badekollimath, Similarly in Gokak taluka the maximum severity of 38.12 per cent was recorded in Gokak followed by Yardal with the severity of 33.59 per cent the least disease incidence $(29.45 \%)$ was recorded in Murkibhavi. In Savadatti taluka maximum severity $(29.15 \%)$ was recorded in Inamhongal village followed by Yaragatti with a severity of 28.27 per cent was recorded and least disease severity was recorded in (18.19\%) Munavalli.

In Vijaypura district, three talukas were surveyed, viz., Vijaypura, Basavana bagewadi and Indi. In Basavana Bagewadi taluka the survey was conducted in three villages. Among them, the maximum disease severity $(40.15 \%)$ was recorded in Managuli followed by Ronihal village $(36.69 \%)$ whereas least disease severity $(28.66 \%)$ was recorded in Agasbal village. Similarly in Vijaypura taluka the maximum severity ( $29.58 \%$ ) was recorded in Jumanal village followed by Vijaypura with the severity of 22.45 per cent and least severity (17.29\%) was recorded in Arakeri.

In Indi taluka maximum severity $(27.69 \%)$ was recorded in Tidagundi and minimum in $(23.10 \%)$ Horti village, respectively. Among the talukas surveyed in Vijaypura district the maximum severity $(35.16 \%)$ was recorded in Basavana Bagewadi taluka and least severity $(22.35 \%)$ was observed in Vijaypura taluka.

\section{Disease scoring scale}

\begin{tabular}{|c|l|}
\hline Score & \\
\hline 0 & No symptom of powdery mildew on leaves. \\
\hline 1 & Small scattered powdery mildew specks covering $1 \%$ or less leaf area. \\
\hline 3 & Small powdery lesions covering 1-10\% of leaf area. \\
\hline 5 & Powdery lesions enlarged covering 11-25\% of leaf area. \\
\hline 7 & Powdery lesions coalesce to form big patches covering $26-50 \%$ leaf area. \\
\hline 9 & Big powdery patches covering $51 \%$ or more of leaf area and defoliation occur \\
\hline
\end{tabular}


Table.1a Survey for severity of cucumber powdery mildew in different districts of northern Karnataka during kharif 2016

\begin{tabular}{|c|c|c|c|c|c|c|c|c|c|c|}
\hline Districts & Taluks & Villages & $\begin{array}{c}\text { Latitude } \\
\left({ }^{\circ} \mathbf{N}\right)\end{array}$ & $\begin{array}{c}\text { Longitude } \\
\left({ }^{\circ} \mathbf{E}\right)\end{array}$ & $\begin{array}{l}\text { Soil } \\
\text { type }\end{array}$ & $\begin{array}{l}\text { Stage of the } \\
\text { crop }\end{array}$ & $\begin{array}{l}\text { Type of } \\
\text { cultivation }\end{array}$ & $\begin{array}{l}\text { Variety/ } \\
\text { Hybrid }\end{array}$ & PDI & Other diseases observed \\
\hline \multirow[t]{14}{*}{ Belagavi } & \multirow[t]{8}{*}{ Bailhongal } & Bailhongal & 15.81 & 74.86 & Black & Flowering & Irrigated & Green long & 22.16 & Downy mildew \\
\hline & & Belavadi & 15.76 & 74.75 & Black & Flowering & Irrigated & Dharwad green & 29.33 & Downy mildew Anthracnose \\
\hline & & Hire Bagevadi & 15.77 & 74.64 & Black & Flowering & Rainfed & Malini F1 & 31.18 & - \\
\hline & & Badekollimath & - & - & Black & Harvesting & Irrigated & Malini F1 & 20.79 & Downy mildew \\
\hline & & Ambadagatti & 15.63 & 74.73 & Black & Flowering & Rainfed & Malini F1 & 24.56 & - \\
\hline & & Dasthikoppa & 15.69 & 74.70 & Black & Flowering & Rainfed & Malini F1 & 36.12 & - \\
\hline & & Kadrolli & 15.69 & 74.73 & Black & Flowering & Irrigated & Malini F1 & 36.17 & - \\
\hline & & M.K.hubli & 15.72 & 74.69 & Black & Flowering & Irrigated & Malini F1 & 30.15 & - \\
\hline & \multicolumn{8}{|r|}{ Taluk mean } & 32.16 & \\
\hline & \multirow[t]{5}{*}{ Belagavi } & Marihal & 15.88 & 74.67 & Black & Harvesting & Irrigated & Malini F1 & 16.12 & Downy mildew \\
\hline & & Sulebhavi & 15.89 & 74.65 & Black & Flowering & Rainfed & Malini F1 & 17.88 & Downy mildew \\
\hline & & K.К.Корра & 15.85 & 74.50 & Black & Flowering & Rainfed & Malini F1 & 10.25 & Downy mildew \\
\hline & & Hulikatti & 15.78 & 74.62 & Black & Flowering & Rainfed & Malini F1 & 24.15 & Downy mildew \\
\hline & & Sutagatti & 15.86 & 74.71 & Black & Harvesting & Irrigated & Malini F1 & 29.18 & Downy mildew anthracnose \\
\hline \multirow[t]{13}{*}{ Belagavi } & \multirow[t]{5}{*}{ Gokak } & Nesargi & 15.90 & 74.77 & Black & Flowering & Irrigated & Malini F1 & 30.12 & - \\
\hline & & Yardal & 15.77 & 74.79 & Black & Flowering & Irrigated & Malini F1 & 33.59 & - \\
\hline & & Murkibhavi & 15.63 & 74.73 & Black & Flowering & Irrigated & Malini F1 & 29.45 & - \\
\hline & & Gokak & 15.86 & 74.84 & Black & Flowering & Irrigated & Malini F1 & 38.12 & Anthracnose \\
\hline & & \multicolumn{7}{|r|}{ Taluk mean } & 32.82 & \\
\hline & \multirow[t]{8}{*}{ Savadatti } & Kurabetta & 16.23 & 74.59 & Black & Flowering & Rainfed & Gullakai & 12.45 & - \\
\hline & & Munavalli & 15.63 & 74.51 & Black & Flowering & Rainfed & Gullakai & 18.19 & - \\
\hline & & Yaragatti & 16.23 & 74.50 & Black & Flowering & Irrigated & Dharwad green & 28.27 & - \\
\hline & & Inamhongal & 15.62 & 75.07 & Black & Flowering & Irrigated & Dharwad green & 29.15 & - \\
\hline & & Hire ulligeri & 15.66 & 75.09 & Black & Harvesting & Irrigated & Greenlong & 27.15 & - \\
\hline & & Savadathi & 15.75 & 75.12 & Black & Harvesting & Irrigated & Dharwad green & 26.15 & - \\
\hline & & & & & & & Taluk mean & 23.85 & & \\
\hline & & & & & & & $\begin{array}{c}\text { District } \\
\text { mean }\end{array}$ & 29.61 & & \\
\hline
\end{tabular}




\begin{tabular}{|c|c|c|c|c|c|c|c|c|c|c|}
\hline Districts & Taluks & Villages & $\begin{array}{c}\text { Latitude } \\
\left({ }^{\circ} \mathbf{N}\right)\end{array}$ & $\begin{array}{c}\text { Longitude } \\
\left({ }^{\circ} \mathbf{E}\right)\end{array}$ & $\begin{array}{l}\text { Soil } \\
\text { type }\end{array}$ & $\begin{array}{l}\text { Stage of the } \\
\text { crop }\end{array}$ & $\begin{array}{c}\text { Type of } \\
\text { cultivation }\end{array}$ & $\begin{array}{l}\text { Variety/ } \\
\text { Hybrid }\end{array}$ & PDI & Other diseases observed \\
\hline \multirow{17}{*}{ Dharwad } & \multirow{10}{*}{ Dharwad } & Garaga & 15.34 & 74.55 & Black & Harvesting & Irrigated & Greenlong & 40.16 & Downy mildew \\
\hline & & Tadakoda & 15.60 & 74.99 & Black & Harvesting & Irrigated & Dharwad green & 40.86 & Anthracnose \\
\hline & & Lokur & 15.72 & 74.79 & Black & Flowering & Rainfed & Gullakai & 35.12 & Downy mildew \\
\hline & & Narendra & 15.36 & 75.12 & Black & Harvesting & Irrigated & Dharwad green & 31.29 & - \\
\hline & & Yethinagudda & 15.48 & 74.98 & Black & Harvesting & Irrigated & Gullakai & 38.15 & - \\
\hline & & Maalapur & 15.46 & 75.00 & Black & Harvesting & Irrigated & Dharwad green & 46.66 & - \\
\hline & & Mrityunjayanagar & 15.46 & 75.01 & Black & Harvesting & Irrigated & Sarpan seeds & 12.25 & Downy mildew \\
\hline & & Marewada & 15.43 & 75.05 & Black & Harvesting & Irrigated & Dharwad green & 14.15 & Downy mildew \\
\hline & & Kavalgeri & 15.49 & 75.07 & Black & Harvesting & Irrigated & Greenlong & 29.16 & - \\
\hline & & & & & & & & Taluk mean & 34.74 & \\
\hline & \multirow[t]{7}{*}{ Hubballi } & Varur & 15.1 & 74.97 & Black & Harvesting & Irrigated & Dharwad green & 28.16 & Downy mildew \\
\hline & & Adaragunchi & 12.97 & 77.56 & Black & Harvesting & Rainfed & Dharwad green & 42.78 & - \\
\hline & & Samshi & 15.21 & 75.30 & Black & Harvesting & Irrigated & Dharwad green & 43.29 & - \\
\hline & & Betadur & 15.22 & 75.19 & Black & Harvesting & Irrigated & Green long & 15.17 & Downy mildew \\
\hline & & Ramankoppa & 15.16 & 75.14 & Black & Harvesting & Irrigated & Gullakai & 13.53 & Downy mildew \\
\hline & & & & & & & & Taluk mean & 31.39 & \\
\hline & & \multicolumn{7}{|c|}{ District Mean } & 33.06 & \\
\hline \multirow[t]{13}{*}{ Haveri } & \multirow[t]{6}{*}{ Byadgi } & Mallur & 14.69 & 75.44 & Black & Harvesting & Rainfed & Dharwad green & 29.66 & Downy mildew \\
\hline & & Angaragtti & 14.66 & 75.44 & Red & Harvesting & Rainfed & Ranebennur local & 40.18 & - \\
\hline & & Kadaramandalgi & 14.64 & 75.51 & Red & Harvesting & Rainfed & Dharwad green & 35.69 & - \\
\hline & & Motebennur & 14.71 & 75.48 & Red & Harvesting & Rainfed & Ranebennur local & 30.15 & - \\
\hline & & Haleshidenur & 14.63 & 75.44 & Black & Harvesting & irrigated & Ranebennur local & 39.28 & - \\
\hline & & & & & & & & Taluk mean & 32.84 & \\
\hline & \multirow[t]{4}{*}{ Hirekerur } & Bannihatti & 14.37 & 75.41 & Red & Floweing & Rainfed & Ranebennur local & 20.48 & Anthracnose \\
\hline & & Hullatti & 14.48 & 75.48 & Red & Harvesting & Rainfed & Ranebennur local & 32.12 & - \\
\hline & & Masur & 14.25 & 75.01 & Red & Floweing & Irrigated & Ranebennur local & 39.55 & - \\
\hline & & Rattihalli & 14.42 & 75.51 & Black & Floweing & Rainfed & Ranebennur local & 30.36 & Anthracnose \\
\hline & \multirow{3}{*}{ Haveri } & Haveri & 14.66 & 75.43 & Red & Harvesting & Irrigated & Ranebennur local & 20.16 & Downy mildew \\
\hline & & Motebennur & 14.63 & 75.42 & Red & Harvesting & Rainfed & Ranebennur local & 26.36 & Downy mildew \\
\hline & & Kerimattihalli & 14.75 & 75.37 & Red & Harvesting & Rainfed & Ranebennur local & 20.15 & Anthracnose \\
\hline
\end{tabular}




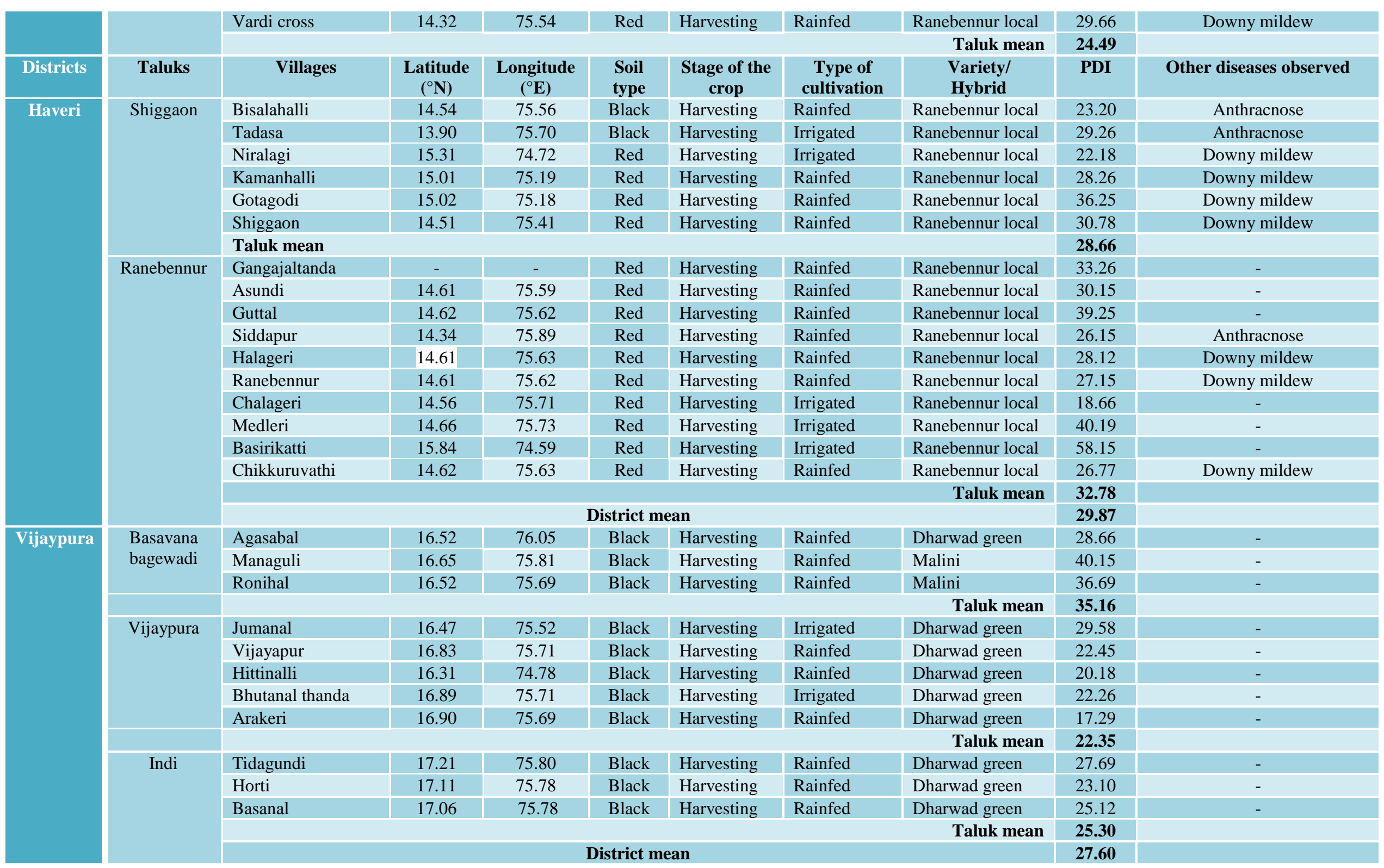


Table.1b Districts and Talukawise incidence of powdery mildew in cucumber

\begin{tabular}{|c|c|c|c|c|}
\hline SI No. & District & Taluk & Mean PDI & $\begin{array}{c}\text { District mean } \\
\text { PDI }\end{array}$ \\
\hline \multirow[t]{4}{*}{1} & \multirow[t]{4}{*}{ Belagavi } & Bailhongal & 32.16 & \multirow[t]{4}{*}{27.21} \\
\hline & & Belagavi & 20.02 & \\
\hline & & Gokak & 32.82 & \\
\hline & & Savadathi & 23.85 & \\
\hline \multirow[t]{2}{*}{2} & \multirow[t]{2}{*}{ Dharwad } & Dharwad & 34.74 & \multirow[t]{2}{*}{33.06} \\
\hline & & Hubballi & 31.39 & \\
\hline \multirow[t]{5}{*}{3} & \multirow[t]{5}{*}{ Haveri } & Shiggaon & 28.66 & \multirow[t]{5}{*}{29.87} \\
\hline & & Haveri & 24.49 & \\
\hline & & Byadgi & 32.84 & \\
\hline & & Ranebennur & 32.78 & \\
\hline & & Hirekerur & 30.62 & \\
\hline \multirow[t]{3}{*}{4} & \multirow[t]{3}{*}{ Vijaypura } & Vijaypura & 22.35 & \multirow[t]{3}{*}{27.60} \\
\hline & & Indi & 25.30 & \\
\hline & & Basavanabagewadi & 35.16 & \\
\hline
\end{tabular}

Table.1c Influence of type of cultivation on severity of cucumber powdery mildew in northern Karnataka during kharif 2016

\begin{tabular}{|c|c|c|c|c|c|}
\hline \multirow{2}{*}{ SI No. } & \multirow[t]{2}{*}{ District } & \multirow[t]{2}{*}{ Taluk } & \multicolumn{2}{|c|}{ Type cultivation } & \multirow{2}{*}{$\begin{array}{c}\text { District } \\
\text { mean PDI }\end{array}$} \\
\hline & & & $\begin{array}{c}\text { Rainfed } \\
\text { (PDI) }\end{array}$ & $\begin{array}{c}\text { Irrigated } \\
\text { (PDI) }\end{array}$ & \\
\hline \multirow[t]{4}{*}{1} & \multirow[t]{4}{*}{ Belagavi } & Bailhongal & 38.74 & 27.72 & \multirow[t]{4}{*}{27.21} \\
\hline & & Belagavi & 17.43 & 22.65 & \\
\hline & & Gokak & - & 32.82 & \\
\hline & & Savadathi & 18.26 & 26.66 & \\
\hline \multirow[t]{2}{*}{2} & \multirow[t]{2}{*}{ Dharwad } & Dharwad & 47.39 & 28.61 & \multirow[t]{2}{*}{33.06} \\
\hline & & Hubballi & 42.78 & 27.36 & \\
\hline \multirow[t]{5}{*}{3} & \multirow[t]{5}{*}{ Haveri } & Shiggaon & 29.62 & 25.72 & \multirow[t]{5}{*}{29.87} \\
\hline & & Haveri & 25.57 & 20.16 & \\
\hline & & Byadgi & 34.99 & 39.28 & \\
\hline & & Ranebennur & 30.12 & 39.00 & \\
\hline & & Hirekerur & 27.65 & 39.55 & \\
\hline \multirow[t]{3}{*}{4} & \multirow[t]{3}{*}{ Vijaypura } & Vijaypura & 19.97 & 22.26 & \multirow[t]{3}{*}{27.60} \\
\hline & & Indi & 25.30 & - & \\
\hline & & Basavanabagewadi & 35.17 & - & \\
\hline \multicolumn{3}{|c|}{ Mean per cent disease index } & 30.23 & 29.32 & \\
\hline
\end{tabular}


Table.1d Influence of variety/hybrids on severity of cucumber powdery in northern Karnataka during kharif 2016

\begin{tabular}{|r|l|c|c|c|c|c|}
$\begin{array}{r}\text { SI } \\
\text { No. }\end{array}$ & Variety/hybrid & \multicolumn{4}{|c|}{ Per cent disease index (PDI) } & Mean \\
\cline { 1 - 7 } & & Belagavi & Dharwad & Haveri & Vijaypura & PDI \\
\hline $\mathbf{1}$ & Malini & 27.19 & - & - & 38.42 & $\mathbf{3 2 . 8 0}$ \\
\hline $\mathbf{2}$ & Dharwad green & 32.85 & 38.17 & 32.68 & 24.04 & $\mathbf{3 1 . 9 5}$ \\
\hline $\mathbf{3}$ & Greenlong & 24.66 & 22.17 & - & - & $\mathbf{2 3 . 4 1}$ \\
\hline $\mathbf{4}$ & Gullakai & 20.72 & 28.93 & - & - & $\mathbf{2 4 . 8 2}$ \\
\hline $\mathbf{5}$ & Ranebennur local & - & - & 30.44 & - & $\mathbf{3 0 . 4 4}$ \\
\hline $\mathbf{6}$ & Sarpan hybrid & - & 12.25 & - & - & $\mathbf{1 2 . 2 5}$ \\
\hline
\end{tabular}

Table.1e Influence of stage of crop on severity of cucumber powdery on different varieties/hybrids in northern Karnataka during kharif 2016

\begin{tabular}{|c|c|c|c|c|c|c|c|c|}
\hline \multirow{2}{*}{$\begin{array}{c}\text { Sl } \\
\text { No. }\end{array}$} & \multirow{2}{*}{$\begin{array}{l}\text { Stage of } \\
\text { the crop }\end{array}$} & \multicolumn{6}{|c|}{ Per cent disease index (PDI) in different variety } & \multirow{2}{*}{$\begin{array}{c}\text { Mean } \\
\text { PDI }\end{array}$} \\
\hline & & Malini & $\begin{array}{c}\text { Dharwad } \\
\text { green }\end{array}$ & $\begin{array}{c}\text { Green } \\
\text { long }\end{array}$ & Gullakai & $\begin{array}{c}\text { Ranebennur } \\
\text { local }\end{array}$ & $\begin{array}{l}\text { Sarpan } \\
\text { hybrid }\end{array}$ & \\
\hline 1. & $\begin{array}{l}\text { Flowering } \\
\text { stage }\end{array}$ & 28.48 & 37.46 & 22.16 & 23.60 & 30.13 & - & 28.36 \\
\hline 2. & $\begin{array}{l}\text { Harvestin } \\
\text { g stage }\end{array}$ & 18.455 & 36.075 & $\begin{array}{c}33.65 \\
5\end{array}$ & 32.65 & 31.705 & 12.25 & 25.42 \\
\hline
\end{tabular}

The severity of powdery mildew ranged from 10.25 to 63.08 Per cent Disease Index (PDI) in northern Karnataka during late kharif, 2016. The highest mean disease severity was recorded in Dharwad district (33.06 PDI) followed by Haveri district (29.87 PDI) and least disease incidence was recorded in Belagavi district (27.21 PDI) and incidence in Vijaypura district was on par with Belagavi district (27.60). This clearly indicates that the disease severity and development depends on factor like location, stage of the crop, cultural practices adopted and susceptibility of the cultivars grown. Apart from this it also depends on congenial conditions prevailing in that area for disease development.

The highest severity of powdery mildew was attributed to the temperature, relative humidity, leaf wetness period, morning dew and sunshine hours prevailed during the crop period, which was favorable for the powdery mildew development and spread. Similar types of observations were made by Cheah et al., (1996) while working with pea.

Prevalence of higher disease intensity in these areas may be due to congenial climatic conditions like relative humidity, cool temperature and susceptible genotypes which might have influenced inoculum multiplication, varied temperature regimes and water content of conidia supported spore germination and infection process of the fungus Erysiphe cichoracearum.

The results are in confirmation with observation of several investigators (Sharmila et al., 2005; Raghavendra, 2005 and Ashtaputre, 2006). Results are also in line with Chaudhary et al., 2014 who reported that capsicum powdery mildew disease severity was differ among the various locations of Himachal Pradesh. 
If the age of the crop coincides with favourable weather parameters development of the disease with very fast and cause a severe loss. Minimum rainfall, cooler nights and high day temperatures were enough for disease development. Wide variation $\left(13-15^{0}\right.$ $\mathrm{C})$ in the maximum and minimum temperature and day and night relative humidity (39.9-51.7 \%) enhances the development of powdery mildew and it was very much noticed in black gram (Anand Singh and Anil Sirohi, 2003).

The highest severity of powdery mildew was attributed to the temperature and relative humidity prevailed during the crop periods which were favourable for the powdery mildew development and spread. Similar types of observations were made in chilli powdery mildew by Ashtaputre et al., (2006).

Among the varieties/hybrids cultivated Malini a hybrid from Seminis Company has covered more area in Belagvi district. Because of heavy plant population and higher doses of fertilizer application by farmers resulting in succulency in plant and favourable microclimate for disease development and host susceptibility similar observation were also made by Koren (1978) and Palti (1971). Intensive cultivation coupled with continuous cropping, where in proximity of infected crops and amount of inoculum present undoubtedly affected the incidence of disease besides creating the favourable environmental conditions (Giladi, 1983, Palti, 1971, Friedrich et al., 1998, Reuveni and Rotem, 1973, Clerk and Ayesu offei, 1967).

From the survey during 2016-17 it was very clear that, the disease incidence was varying in four different districts. The mean disease severity was more in Dharwad district (33.06 PDI) followed by Haveri district (29.87 PDI) and average mean percent disease severity (PDI) was observed in Belagavi (27.21 PDI) district followed by Vijaypuraa (27.60 PDI). The maximum disease severity of 63.08 per cent was observed in Bailwad cross village of Bailhongal taluka, Belagavi district where prevailing fertile black soils resulted in luxurious growth of the crop and prevailing dry condition has helped the pathogen to build up the inoculum hence, the disease intensity was more severe there.

\section{References}

Anand Singh and Anil Sirohi, 2003, Effect of some weather parameters on the development of powdery mildew (Erysiphe polygoni) in black gram. $\mathrm{Pl}$. Dis. Res., 18 (1): 63-64.

Anonymous, 2015-16, Handbook of horticulture statistics, GOI, Ministry of agriculture. Department of agricultural sciences and co-operation. New Delhi. pp.: 14-16.

Ashtaputre, S. A., 2006, Studies on loss assessment, epidemiology and management of powdery mildew of chilly caused by Leveilulla taurica (Lev.) Arn. Ph. D. Thesis, Univ. Agric. Sci, Dharwad, Karnataka (India).

Awad, N. G. H., 2000, Reaction of some cucurbits against physiological and histopathological changes. Arab Univ. J. Agric. Sci., 8: 829-851.

Chaudhary, J., Banyal, D. K., Singh, A. and Mehra, A. K., 2014, Status and distribution of powdery mildew of capsicum under protected cultivation in Himachal Pradesh and its management through fungicides. Pl. Dis. Res., 29 (2): 248.

Cheah, L. H., Page, B. B. C. and Cox, J. K., 1996, Epidemiology of powdery mildew (Sphaerotheca fuliginea) of squash Proc. 49th N. Z. Pl. Prot. Conf. 147-151.

Clerk G. C. and Ayesu offei, E. N., 1967, Conidia and conidial germination in 
levillula taurica (Lev.) Arn. Annual botany, 31:749-754.

Friedrich, S., Boyle, C., Munack, A. and Tantau, H. J., 1998, Simulation of infection probability of powdery mildew in winter wheat. In: proceedings of 2rd IFAC Workshop, Hanover, Germany, 28 September to October, 1997, P.7.

Gangwar, S. and Mishra, K., 2014, Observations on the spectrum of powdery mildew on cucurbits in Faizabad mandala of U. P. India. J. L. Sci., 3 (2): 105-108.

Giladi, 1983, the amount of systemic fungicide tridemefon required in pepper leaves for the control of Levillula taurica (lev.) Arn. Ph. D. Thesis, herbrew university, Jerusalem. 87- 94.

Koren, A., 1978, Aspects of controlling levilulla taurica in canning tomatoes. $\mathrm{Ph}$. D. Thesis. Herbrew University. Jerusalem. P. 27.

Mayee, C. D. and Datar, V. V., 1986, Phytopathpmety. Technical Bulletin-1 (special bulletin-3), Marathwada
Agricultural University, Parbhani, Maharasthra, India, p. 29.

Palti, J., 1971, Biological characteristics, distribution and control of levilulla taurica (lev.) Arn. Phytopathol. meditarranean. 10:137-153.

Raghavendra, 2005, Epidemiology and management of chilli powdery mildew caused by Leveillula taurica (Lev.) Arn. M. Sc. (Agri.) Thesis, Univ. Agric Sci., Dharwad, Karnataka (India).

Reuveni, R. and Rotem, J., 1973, Epidemics of levilulla taurica on tomatoes and Peppers as affected by conditions of humidity. Phytopathol. 76:153-157.

Sharmila, A. S., Kachapur, M. R., Patil, M. S., 2005, Field evaluation of chilly genotypes for resistance to powdery mildew. Karnataka J. Agric. Sci.19 (1): 166-167.

Sitterly, W. R., 1972, Powdery Mildews of Cucurbits. The Powdery Mildews, London: Academic Press Inc. Ltd., pp. 359-379.

Wheeler, B. E., 1969, An Introduction to Plant Disease, John Wiley and Sons Ltd., London, p. 301.

\section{How to cite this article:}

Parameshwar Naik, H. and Shripad Kulkarni. 2018. Survey of Powdery Mildew in Major Cucumber Growing Areas of Northern Karnataka. Int.J.Curr.Microbiol.App.Sci. 7(04): 30153024. doi: https://doi.org/10.20546/ijcmas.2018.704.341 